\title{
Exercise of the Privilege Against Self-Incrimination by Witnesses and Codefendants: The Effect Upon the Accused
}

The privilege against self-incrimination has assumed a special importance in Supreme Court decisions because the Justices see it as a vital bulwark of claimants' individual liberty. ${ }^{1}$ But allowing a witness or a defendant to refuse to answer questions may have important effects beyond shielding the individual from the inquisitorial power of the prosecuting authorities. Specifically, it may allow a witness to refuse to testify at the trial of someone else, with the result that evidence relevant to that defendant's guilt or innocence is excluded. For example, two men might be named as accomplices in crime. If the two are tried jointly, either or both may refuse to take the stand. If they are tried separately, the one not then on trial may refuse to answer questions if called as a witness by either side. Such a refusal raises not only the problem whether one who claims the privilege can be forced to testify, but an even more vexing problem whether either the prosecutor or the defendant should be allowed to draw any inference from the refusal to testify. Finally, if the privilege against self-incrimination makes it impossible for a defendant to obtain testimony essential to his defense, it may be difficult to conclude that he has had a fair trial.

\section{Assertion of the Privilege by a Wrtness}

In a typical criminal trial situation the prosecutor calls a witness who is alleged to be the defendant's accomplice but who is not a codefendant at the defendant's trial. This witness then refuses to answer questions about the crime, and his claim of the privilege against self-incrimination is sustained by the judge. On appeal, the defendant asks for a new trial on the ground that the witness' invocation of privilege in the presence of the jury unfairly prejudiced his case.

The defendant's concern is well founded, for the refusal of the witness

1 The Supreme Court has described the privilege as an "essential mainstay" of the American system of criminal prosecution. Malloy v. Hogan, 378 U.S. 1, 7 (1964). "The Fourteenth Amendment secures against state invasion the same privilege that the Fifth Amendment guarantees against federal infringement-the right of a person to remain silent unless he chooses to speak in the unfettered exercise of his own will, and to suffer no penalty . . . for such silence." Id. at 8 . 
to testify will quite probably be harmful to a defendant. The jury is likely to infer that the witness, at least, is guilty of the crimes with which the prosecutor and the evidence have connected him and about which he refuses to answer questions. ${ }^{2}$ Since other evidence in the case connects the witness and the defendant to the crime, the taint of guilt attached to the witness may carry over to the defendant. The harm will be vastly compounded if the prosecutor is allowed to ask leading questions linking the defendant and the witness. The refusals to reply may be taken by the jury as incriminating admissions, and the prosecutor will have succeeded in putting his own testimony into the mouth of the witness. $^{3}$

Whether these possible inferences are unfair is a problem for the law of evidence. The constitutional privilege against self-incrimination by itself does not demand that they be condemned. The prosecutor is forbidden to attempt to create inferences from a defendant's refusal to take the witness stand, not primarily because the refusal to take the stand logically lacks probative value in showing guilt, but because defendants should be able to exercise their constitutional rights without being penalized. ${ }^{4}$ When inferences are drawn from a witness' claim of the

2 The instruction in the usual criminal case that the jury is to draw no inferences from a defendant's refusal to testify is some indication that courts believe that juries are apt to assume that silence in the face of accusation indicates guilt. There is disagreement among judges and commentators as to whether a claim of the privilege is logically probative of guilt. Compare Slochower v. Board of Educ., 350 U.S. 551, 557-58 (1956) (“ $[\mathrm{A}]$ witness may have a reasonable fear of prosecution and yet be innocent of any wrong-doing. The privilege serves to protect the innocent who otherwise might be ensnared by ambiguous circumstances."), with United States v. Maloney, 262 F.2d 535, 537 (2d Cir. 1959) (L. Hand, J.) ("Such refusals [to answer questions] have been uniformly held not to be a permissible basis for inferring what would have been the answer, although logically they are very persuasive."). See generally Meltzer, Required Records, The McCarran Act, and the Privilege Against Self-Incrizhination, 18 U. CHI. L. REv. 687 (1951).

3 In Washburn v. State. 164 Tex. Crim. 448, 299 S.W.2d 706 (1957), the prosecutor asked the witness a series of leading questions while the witness continued to claim his privilege. The Texas Court of Criminal Appeals reversed the conviction because, under Texas law, the claims/ of privilege were not admissible evidence. Even if the witness' refusal to testify were thought to have some probative value as evidence of the guilt of the defendant, it would still be improper to allow a prosecutor to interrogate him on the stand. The fact that truthful answers would tend to incriminate the witness does not mean that they would support the innuendoes of the prosecutor. Yet in Commonwealth v. Granito, 326 Mass. 494, 95 N.E.2d 539 (1950), the prosecutor was allowed to ask seventeen highly damaging leading questions for which virtually no foundation was laid. The conviction was affirmed because a curative instruction was given. See text accompanying notes 26-29 infra.

4 Griffin v. California, 380 U.S. 609,615 (1965), holds that the fifth amendment, applicable to the states through the fourteenth amendment, "forbids either comment by the prosecution on the accused's silence or instructions by the court that such silence is evidence of guilt." Such a comment "cuts down on the privilege by making its assertion costly." It is true that the opinion for the Court by Mr. Justice Douglas states that an 
privilege, the witness is not penalized or coerced into surrendering his privilege since he is not on trial. Consequently, the United States Supreme Court has recognized that the inferences raise issues of "evidentiary trial error" independent of the privilege. ${ }^{5}$

A more substantial objection to such inferences is that they are so inherently ambiguous that whatever probative value they have is outweighed by the danger that the jury will attach far more weight to them than they logically deserve. Refusals to answer may or may not mean that the witness is guilty, but even assuming that truthful answers to relevant questions would incriminate the witness it does not follow that they would incriminate the defendant unless a connection between the witness and defendant has been established. Furthermore, as a practical matter he cannot clarify these ambiguous "replies" by cross-examination, since the witness will probably refuse to answer the defendant's questions as well as those of the prosecutor. Impossibility of effective cross-examination is always a strong reason for excluding evidence; in fact, it constitutes the modern justification for the hearsay rule. ${ }^{6}$

This is not to say that inferences from the claim of privilege have no probative value whatever. They do tend to bolster somewhat the other evidence in the case that incriminates both the witness and the defendant, assuming that the witness' refusal to answer questions is some indication, however slight, of the witness' own guilt. The testimony of $W$ that he saw $A$ and $B$ commit a crime together is certainly strengthened

inference from the silence of the accused is not "natural or irresistible," because other inferences are possible. However, it is in the nature of inferences from circumstantial evidence that they do not necessarily exclude other possibilities. See text accompanying note 7 infra.

5 "In turning to the petitioner's argument that his conviction must be set aside because of the circumstances described, we emphasize at the outset what this case does not involve. No constitutional issues of any kind are presented. The petitioner does not claim any infringement of his Fifth Amendment privilege against self-incrimination. He does not contend that the [witnesses] . . . were in any way prejudiced by their assertion of this constitutional privilege. All that this case involves, in short, is a claim of evidentiary trial error." Namet v. United States, 373 U.S. 179, 185 (1963). But see Douglas v. Alabama, 380 U.S. 415 (1965), which held that the confrontation clause of the sixth amendment forbids the use of inferences from the claim of privilege which add "critical" weight to the prosecution's case, if the defendant is unable to effectively cross-examine the claimant with regard to the inferences.

6 See, e.g., 5 WIGMORE, Evidence $\S 1362$ (3d ed. 1940): "In the preceding passages, the testing required by the Hearsay rule is spoken of as cross-examination under oath. But it is clear beyond doubt that the oath, as thus referred to, is merely an incidental feature customarily accompanying cross-examination, and that cross-examination is the essential and real test required by the rule." The analogy between inferences from the claim of privilege by a witness and hearsay testimony was impliedly drawn by L. Hand, J., in United States v. Maloney, 262 F.2d 535, 537 (2d Cir. 1959): "[I]t is clear, not only that the presumed answer has not the sanction of an oath, but-what is even more importantthat the accused cannot cross-examine." See also Douglas v. Alabama, 380 U.S. 415 (1965). 
if, at the trial of $A, B$ refuses to answer questions on the grounds that his replies might tend to incriminate him. Of course, $B$ 's refusal to answer may mean that he alone is guilty, or that neither $B$ nor $A$ is guilty but $B$ has been advised by counsel that it would be safer to remain quiet. Evidence, however, does not have to be completely free from alternative interpretations to be logically probative of guilt. If it tends to increase the likelihood of guilt it is admissible unless there is a special reason for exclusion. ${ }^{7}$ The special reasons in this case are the impossibility of effective cross-examination and the possibility that the jury may give inferences from the claim of privilege more weight than they deserve. ${ }^{8}$

The federal courts and most of the state courts have held that a judge may not allow the prosecutor to attempt to raise inferences from a witness' claims of privilege by comments to the jury; on the contrary, he must instruct the jury that they are to draw no such inferences. ${ }^{9}$ The law only becomes murky when the prosecutor attempts to avail himself of the inference without commenting upon the claims of privilege. This he can accomplish by asking a claimant-witness questions phrased to raise the inference in the minds of the jury. Having done so it is doubtful that a curative instruction could erase the impact of the prosecutor's questions.

7 There has naturally been much variety in statements of the rule on the degree of probative value required for admissibility. See, e.g., MORGAN, Maguire \& WeInsteIn, Cases ON Evidence 326-28 (1957); I Wigmore, EVIDENCE § 32 (3d ed. 1940); Meltzer, supra note 2.

8 The most common example of evidence of admitted probative value which is normally excluded because it is too persuasive is evidence of a criminal defendant's evil character or prior criminal conduct. "The inquiry is not rejected because character is irrelevant; on the contrary, it is said to weigh too much with the jury and to so overpersuade them as to prejudge one with a bad general record and deny him a fair opportunity to defend against a particular charge." Michelson v. United States, 335 U.S. 469, 475-76 (1948). Courts which say that inferences from the claim of privilege have no probative value may in fact mean that they have nowhere near the value that the jury is apt to give them.

9 Billeci v. United States, 184 F.2d 394 (D.C. Cir. 1950); Beach v. United States, 46 Fed. 754 (1890); People v. Glass, 158 Cal. 650, 112 Pac. 281 (1910); De Gesualdo v. People, 364 P.2d 374 (Colo. 1961); Powers v. State, 75 Neb. 226, 106 N.W. 332 (1905); State v. Harper, 33 Ore. 524, 55 Pac. 1075 (1899); McClure v. State, 95 Tex. Crim. 53, 251 S.W. 1099 (1923). Contra, State v. Snyder, 244 Iowa 1244, 59 N.W.2d 223 (1953); State v. Addington, 158 Kan. 276, 147 P.2d 367 (1944).

Related problems are presented when the witness or the defendant claims the intermarital, lawyer-client, or doctor-patient privilege. Such a claim of privilege may be very probative indeed, especially when the defendant asserts the privilege to prevent the witness from testifying. To allow an adverse inference, however, would frustrate the policy of these privileges by making their exercise onerous. See San Fratello v. United States, 340 F.2d 560 (5th Cir. 1965); People v. Gill, 143 Cal. App. 2d 146, 299 P.2d 682 (1956); State v. Tanner, 54 Wash. 2d 535, 341 P.2d 869 (1959). 
However, calling a witness to the stand may have been justified even though he subsequently invokes the privilege. The prosecutor may not know that the privilege will be invoked, he may believe that the judge will not sustain the claim of privilege, or he may hope that the witness will be willing to answer some questions even if he is allowed to decline to answer others. ${ }^{10}$ Although the prosecutor's motives are totally pure, or can be made to appear so, the result may be that the jury is given an opportunity to draw the inferences that the rules say they should not draw.

Unintentional raising of the inference was the problem in Namet $v$. United States. ${ }^{11}$ The prosecutor called two witnesses after he was informed by their counsel and defendant's counsel that they would assert the privilege. Both witnesses had previously pleaded guilty to a charge similar to that facing the defendant and were awaiting sentence. The Court held that reversible error had not been committed; the prosecutor could reasonably have believed that the claim of privilege was not valid because the witnesses had given some unprivileged testimony, and the objectionable inferences did not add "critical weight" to the case. In effect, the need for evidence was held to outweigh the incidental objectionable inferences.

Writing for the Court, Mr. Justice Stewart explained that the circuit court cases reversing convictions because of the claim of privilege by a witness on the stand rest on one or both of two factors; either the prosecutor was guilty of "misconduct," or "critical weight" was added to the case against the defendant by inferences from the witness' refusal to answer. Although prosecutor "misconduct" often involves the asking of leading questions-a "flagrant attempt to build [a] . . . case out of

10 Some courts have held that prosecutors were justified in calling witnesses to the stand even though they were certain to claim the privilege, on the theory that if the prosecutor does not call the witness, who has been named as an accomplice, the jury may infer that he is concealing evidence favorable to the defendant. United States v. Gernie, 252 F.2d 664 (2d Cir.), cert. denied, 356 U.S. 968 (1958); United States v. Romero, 249 F.2d 371 (2d Cir. 1957); United States v. Hiss, 185 F.2d 822 (2d Cir. 1950), cert. denied, 340 U.S. 948 (1951); Commonwealth v. Donatelli, 202 Pa. Super. 565, 198 A.2d 338 (1964). This justification was explicitly rejected in United States v. Maloney, 262 F.2d 535 (2d Cir. 1959) (dictum). It is clearly erroneous when applied to examination by the prosecutor after the initial claim of privilege. Even if the witness is excused immediately after indicating that he will not testify, the prosecutor may have gained much more than simply the destruction of an adverse inference. Moreover, it is doubtful that the jury will draw the adverse inference unless defense counsel points it out to them, and they might just as easily assume that it is the defendant who is concealing evidence by not calling the alleged accomplice as a witness. Consequently, the best solution is to keep the witness off the stand, and to allow the prosecutor to explain to the jury that the witness refused to testify only if defense counsel attempts to draw the adverse inference that the prosecution is concealing evidence.

11373 U.S. 179 (1963). 
inferences arising from use of the testimonial privilege"12 - prosecutors invite reversal whenever they put a witness on the stand with knowledge that he will claim the privilege unless they have reason to believe that the judge will order the witness to answer questions..$^{13}$ However, in Namet the prosecutor's motives were untainted, and the few invocations of privilege added little weight to an already imposing case, so that the conviction was affirmed. ${ }^{14}$

Mr. Justice Stewart's discussion of when reversal is required, although largely dictum, fairly describes the cases. However, the elusiveness of any standard of prosecutor "misconduct" in an adversary system is well demonstrated by the facts of Namet itself. Although the prosecutor may originally have supposed that the judge would not allow the witnesses to decline to answer questions, the judge had sustained their claim of privilege before the incriminating questions were asked. ${ }^{15}$ And if the prosecutor hoped to obtain valuable testimony, he nonetheless made no effort to avoid questions that were certain to raise the claim of privilege. ${ }^{16}$ Thus where Mr. Justice Stewart saw unavoidable slips, Mr. Justice Black, in dissent, saw sly strategy. ${ }^{17}$

It is easy to see why courts have declined to reverse cases in which such inferences as the jury might have drawn appeared not to add critical weight to the case. Yet the desire to avoid reversal has resulted in a standard of prosecutor "misconduct" which has at times been lax enough to allow prosecutors to bend the rules a little in their own favor. Convictions have been affirmed when the prosecutor's deliberate attempt to raise the inference was only a "minor lapse," 18 and prosecutorial motives have been excused by judicial rationalizations that, after all, the witness might have changed his mind on the stand. ${ }^{19}$ Appellate courts have also affirmed convictions when they have concluded that the trial court erred in sustaining the claim of privilege. ${ }^{20}$ However,

12 Id. at 186.

$13 \mathrm{Mr}$. Justice Stewart's entire discussion of the "prosecutor misconduct" issue is directed to whether or not the prosecutor knew that the witness would claim the privilege.

14 The trial court gave an apparently erroneous instruction, but the defendant did not properly object to it. 373 U.S. at $190-91$. The instruction is worth quoting as an indication of the difficulties inherent in giving a sensible instruction under existing law: "Nor should any inference be drawn against [the defendant] ... because the [witnesses] ... refused to testify, unless it would be a logical inference that would appeal to you as having a direct bearing upon the defendant's guilt." $I d$. at 185 .

15373 U.S. at 181-82.

$16 \mathrm{Id}$. at 184.

17 "Certainly the prosecutor must have thought the refusals to answer would help the State's case; otherwise, he would not have asked the questions that he knew would not be answered." 373 U.S. at 191 (Black, J., dissenting).

18 United States v. Hiss, 185 F.2d 822 (2d Cir. 1950), cert. denied, 340 U.S. 948 (1951).

19 People v. Kynette, 15 Cal. 2d 731, 104 P.2d 794 (1940).

20 United States v. Gernie, 252 F.2d 664 (2d Cir.), cert. denied, 356 U.S. 968 (1958); 
the harm to the defendant from misleading inferences is no less because the witness ought to have been ordered to testify. ${ }^{21}$ Still, the clever or daring prosecutor may be able to raise the objectionable inferences if the court is willing to give his motives the benefit of the doubt.

Even in absence of prosecutor misconduct Namet requires that the conviction be reversed in any case if inferences from the claim of privilege added "critical weight" to the prosecution's case. This determination requires delicate judgment, since one can only speculate on the importance such inferences might have had on the minds of the jury. Where the conviction can be upheld, the admissible evidence in the case must be sufficient to support it. But if the prosecutor deliberately evokes claims of privilege, on whatever justification, he certainly does so because he thinks the resulting inferences might be important to his case. $^{22}$ Otherwise, he would not run the risk of reversal. Hence, the question will often arise in the most difficult of cases.

In most cases there is no need for the courts to wrestle with these problems. If one believes that inferences from the invocation of the privilege should not be drawn, and most state and federal cases are in accord on this point, ${ }^{23}$ certainly it is worth some effort to prevent them from arising during the trial. One way to accomplish this was suggested in the government's brief in the Namet case. ${ }^{24}$ When defendant's counsel knows or suspects that someone whom the prosecutor may call as a witness is likely to plead the privilege, he should be entitled to a hearing without the presence of the jury before the witness is called. At the hearing, the judge could determine which questions the witness would be likely to refuse to answer and whether the refusals would be justified. ${ }^{25}$

United States v. Romero, 249 F.2d 371 (2d Cir. 1957); United States v. Cioffi, 242 F.2d 473 (2d Cir.), cert. denied, 353 U.S. 975 (1957). In all of these cases the sustaining of the claim of privilege was held to be error because the witness had already been convicted for the crime about which the questions were asked. This reasoning ignores the possibility of conviction for related offenses growing out of the same transaction, and the possibility that state authorities might obtain a separate conviction after the federal conviction. Apparently a witness is now entitled to claim his privilege even after he has been convicted, Malloy v. Hogan, 378 U.S. 1, 11-14 (1964), and thus these cases are of doubtful validity today.

21 The Supreme Court recently reversed a state case in which the prosecutor read from a witness' previous out-of-court confession to "refresh" the witness' memory. The witness claimed the privilge whenever the prosecutor asked whether he recalled making a particular statement. The Court held that it was unnecessary to decide whether the witness properly invoked the privilege. Douglas v. Alabama, 380 U.S. 415 (1965).

22 See the dissenting opinion of Mr. Justice Black in Namet v. United States, quoted in note 17 supra.

23 See cases cited note 9 supra.

24 "The Government has suggested that in appropriate circumstances the defendant may be entitled to request a preliminary screening of the witness' testimony, outside the hearing of the jury." 373 U.S. at 190 n.9. This footnote from the Court's opinion may be construed as a hint to the district courts.

25 A delicate problem would be presented by the witness who refused to testify even 
He could then specify what lines of questioning the prosecutor may pursue. Any significant departure from this ruling should be grounds for a mistrial, without speculation as to whether the prejudicial effect was great or small. Although exceptional cases may raise problems that are not so easily solved-witnesses may change their minds or the defendant may not suspect that a witness will claim the privilege-the possibility of unavoidable problems is no argument for failing to take steps to avoid the avoidable ones.

Perhaps the greatest virtue of the pre-trial hearing is that it should largely eliminate the problem of whether instructions to the jury not to draw inferences from the witness' claim of privilege suffice to cure any possible prejudice. Many cases have affirmed convictions because curative instructions were given, ${ }^{26}$ even when there could be little doubt that the prosecutor made as much use of the claims of privilege as he dared. ${ }^{27}$ Such instructions are not only of doubtful efficacy, they may actually compound the harm by pointing out to the jury inferences they might otherwise have missed. Judges have not always been blind to this, ${ }^{28}$ but reliance on curative instructions has been justified on the grounds that they are no more inappropriate here than they are in other situations in which their use has always been accepted. ${ }^{29}$ The instruction places defendant's counsel in an unenviable dilemma: if he re-

though ordered to do so by the court. After Malloy v. Hogan, 378 U.S. I (1964), this problem is not likely to arise since the witness is entitled to refuse to speak unless it is perfectly clear that the answer cannot possibly tend to incriminate him. The witness can be ordered to testify only if he is granted complete immunity. Murphy v. Waterfront Comm'n, 378 U.S. 52 (1964). If the witness has been granted immunity and still refuses to testify he should not be put on the stand because his replies still lack probative value.

Malloy v. Hogan and Murphy v. Waterfront Comm'n also render moot whether the prosecutor should be allowed to appeal a judge's ruling that the witness is entitled to claim his privilege. Only in rare circumstances will the judge be in error if he sustains the privilege.

20 United States v. Gernie, 252 F.2d 664 (2d Cir.), cert. denied, 256 U.S. 968 (1958); United States v. Romero, 249 F.2d 371 (2d Cir. 1957); United States v. Hiss, 185 F.2d 822 (2d Cir.), cert. denied, 340 U.S. 948 (1951); People v. Kynette, 15 Cal. 2d 731, 104 P.2d 794 (1940); Commonwealth v. Granito, 326 Mass. 494, 95 N.E.2d 539 (1950). In United States v. Maloney, 262 F.2d 535 (2d Cir. 1959), the conviction was reversed solely for lack of the instruction, although the defendant had not asked for it.

27 E.g., Commonwealth v. Granito, 326 Mass. 494, 95 N.E.2d 539 (1950). The ultimate absurdity of the curative instruction rule was reached in People v. Kynette, 15 Cal. 2d 731, 104 P.2d 794 (1940), where the court noted with approval that the district attorney had taken pains to repeat the court's instruction to the jury in his closing argument.

28 "As res integra, it is doubtful whether such admonitions are not as likely to prejudice the interest of the accused as to help them, imposing, as they do, upon the jury a task beyond their powers: i.e., a bit of 'mental gymnastics,' as Wigmore $\S 2272$ calls it, which it is for practical purposes absurd to expect of them." United States v. Maloney, 262 F.2d 535, 538 (2d Cir. 1959) (L. Hand, J.).

29 "However, the situation is in substance the same as when a judge tells the jury not to consider the confession, or admission, of one defendant in deciding the guilt of another, tried at the same time; and, since it is settled that this rubric will cure that error . . . we 
quests the instruction the "error" may be deemed cured by it, and if he does not request the instruction he may be deemed to have waired his right to object on appeal. The pre-trial procedure suggested above should normally prevent the jury from hearing the witness claim his privilege in the first place, thus bypassing the instruction problem. If the procedure is not utilized, or if unforeseen circumstances result in the jury hearing the claim of privilege when the prosecutor is not at fault, there is still no reason for placing reliance on instructions that are so widely thought to be an empty ritual. ${ }^{30}$

There remains the problem that the Supreme Court faced in the Namet case, which simply is not susceptible of a satisfactory solution. The jury will sometimes hear questions answered with a claim of privilege through no fault of the prosecutor. Courts are naturally reluctant to reverse if the error appears to be harmless, and in such a situation the resulting inference will practically never be a major part of the prosecutor's case, unlike a confession or direct testimony. The difficult problem of estimating the importance the jury attached to the inference $^{31}$ can be avoided only by adopting a rule of automatic reversal, which would permit any witness to win the defendant a new trial simply by asserting the privilege on the stand. Hence, the harmless error problem must remain, except insofar as it can be circumvented by the pretrial procedure.

All of the above discussion has assumed that it is the prosecutor who desires to call the witness, but there are cases in which it is the defendant who wishes to call a witness who fears self-incrimination. Should the defendant likervise be forbidden to make use of inferences from the witness' refusal to testify? The rationale for excluding inferences from the claim of privilege as evidence is that they are unreliable, because the refusal to answer is necessarily ambiguous. But it was seen that they are not totally devoid of probative value, and might in some cases justifi. ably be admissible as evidence if it were not for the impracticability of cross-examination and, possibly, the fear that the jury will give undue weight to the inferences. ${ }^{32}$ However, the fear that the jury will give

do not see why it should not cure the error here." United States v. Maloney, 262 F.2d 535, 538 (2d Cir. 1959) (L. Hand, J.).

30 The most recent cases have reversed convictions even though the curative instruction was given. San Fratello v. United States, 340 F.2d 560 (5th Cir. 1965); Fletcher v. United States, 332 F.2d 724 (D.C. Cir. 1964).

31 For this reason Mr. Justice Black did not want to apply a harmless error standard in Namet v. United States, 373 U.S. 179, $191-92$ (1963) (Black, J., dissenting). This is consistent with the approach taken in recent cases in which the court has prefened to set rules for automatic reversal rather than to examine the prejudicial effect of the error in each case. See, e.g., Escobedo v. Illinois, 378 U.S. 478 (1964); Gideon v. Wainwright, 372 U.S. 335 (1963).

32 Sce text accompanying notes 5-8 supra. 
them undue weight does not apply to evocations of the privilege by the defendant, since it is unlikely that the jury will be prejudiced against the prosecutor by such claims. Moreover, cross-examination by the prosecutor, if permitted, will probably be more effective in raising inferences detrimental to the defendant than was the defendant's effort to raise inferences in his own favor, because the defendant's motive in attempting to raise such inferences will be more open to suspicion. Normally the defendant would be trying to raise an inference that the witness alone is guilty of the crime, or is concealing evidence of value to the defense. Although the raising of this inference should usually be forbidden because it lacks probative value, there may be some cases in which it tends to prove the innocence of the defendant. For example, the prosecutor's theory may be that the defendant alone committed the crime. Unless there is convincing independent evidence linking the witness to the crime, it is unlikely that the jury will give undue weight to inferences favorable to the defense. In such circumstances defendants should be permitted to call witnesses who will claim the privilege.

Mr. Justice Stewart's opinion in Namet made it clear that the Court viewed the issue of prosecutorial use of inferences from the claim of privilege by a witness as a matter for the law of evidence, and not as a necessary component of the privilege itself. ${ }^{33} \mathrm{~A}$ recent case has shown that this narrow view may no longer reflect the Court's position and that the use of these inferences may raise constitutional problems. In Douglas $v$. Alabama ${ }^{34}$ the Court reversed a state conviction because a witness who invoked the privilege against self-incrimination was questioned in detail at the trial about a confession he had purportedly made. In effect, the witness' out-of-court confession was introduced against the defendant under circumstances which made effective cross-examination impossible. The Court held that this violated the sixth amendment right to confront witnesses and that this right applies to the states through the fourteenth amendment. The citation of Namet as authority in the Douglas opinion may mean that state as well as federal trial courts will be bound by the Namet standards and would do well to consider allowing the kind of hearing Namet suggests.

\section{Refusals of a Codefendant to Testify at a Joint Trial}

When two defendants are tried jointly, the exercise by one of them of his right not to take the stand may have important consequences for the defense of the other. If defendant $A$ wishes to call defendant $B$ as a witness, $B$ 's exercise of the privilege obviously makes this impossible. And 
if $A$ intends to prove his own innocence by casting all the blame for the crime on $B, B$ is practically certain to refuse to be of help. Even if $A$ does not wish to call $B$ as a witness, he may want to comment to the jury on $B$ 's unwillingness to take the stand, or on the prosecutor's failure to introduce $B$ as a witness against him. This comment may in turn infringe the rights of $B$, who is entitled to exercise his privilege without adverse comment.

All of these problems could be avoided if defendants could always obtain separate trials on request. Ordinarily, however, trial courts have been reluctant to exercise their discretionary power to grant severances. Joint trials eliminate the necessity of using the same evidence and witnesses in a series of trials, alleviate delays in bringing defendants to trial, and prevent the inefficient presentation of identical issues of law for determination by two or more courts. If an automatic severance were granted whenever one defendant would be better off in a separate trial, the increase in the number of trials might severely strain trial administration and the patience of witnesses. Perhaps for these reasons defendants have no right to a severance when a joint trial will or may place them at a disadvantage. In the federal courts, severances have been denied to defendants even though evidence that could not be introduced against them in a separate trial would be admitted against another defendant in the joint trial, and even though one defendant was not named in each count of the indictment. ${ }^{35}$ The fact that juries in joint trials may convict the defendants en masse without examining their separate defenses has been observed many times. ${ }^{36}$ Still the joint trial flourishes, and as yet the convenience of trial administration has usually been given precedence over the interests of defendants.

The joint trial received a severe setback, however, in De Luna $v$. United States, ${ }^{37}$ which may have done more to confuse than clarify the issue. The trial court had allowed counsel for one defendant, who was attempting to place all the blame for the crime on his codefendant, to comment to the jury on the codefendant's failure to testify. The gist of the comment, which was repeated several times, was that the testifying defendant was frank and honest enough to tell his version of the story on the witness stand, whereas the codefendant showed his own guilt by hiding behind a wall of constitutional silence. ${ }^{38}$ On appeal, the Fifth

35 Fed. R. Crim. P. 8(b); Daley v. United States, 231 F.2d 123, 125 (lst Cir.), cert. denied, 351 U.S. 964 (1956). See Note, Joint and Single Trials under Rules $s$ and 14 of the Federal Rules of Criminal Procedure, 74 YALE L.J. 553 (1965).

36 See, e.g., People v Krugman, 44 Misc. 2d 48, 49, 252 N.Y.S.2d 846, 848-49 (Sup. Ct. 1964).

37308 F.2d 140 (5th Cir. 1962), rehearing denied, 324 F.2d 375 (1963).

$38 \mathrm{Id}$. at 142 n.1. 
Circuit reversed the conviction of the silent defendant on the ground that his right not to take the stand was infringed by the comment of the other defendant's counsel, just as it would be infringed if the prosecutor made a similar comment. ${ }^{39}$ The court also stated that counsel for the testifying defendant was entitled to make the comment because of the defendant's "right to confrontation." 40 Recognizing that this result would require separate trials whenever defendants assert adverse defenses, the court held that the rights of each defendant would be protected by no less drastic a remedy. ${ }^{41}$

Judge Wisdom's opinion for the majority presents an impressive and scholarly analysis of the purposes and history of the privilege against self-incrimination and concludes that the silent defendant was entitled to a new trial. ${ }^{42}$ In sharp contrast is his dictum that the other defendant's counsel had a right and duty to comment on the silent defendant's exercise of his privilege. This dictum is included almost casually, without citation of authority and without satisfactory analysis. The right to comment is said to rest on the "right to confrontation," which allows a defendant "to invoke every inference from ... . [another defendant's] absence from the stand." 43 This statement apparently intends to refer to the right of a defendant "to be confronted with the witnesses against him," which is guaranteed by the sixth amendment.44 However, the silent defendant is not a witness at all, and the court did not say why the right to confront witnesses includes a right to comment on the absence of people who are not witnesses.

This mysterious reference to the right of confrontation aside, what the court apparently had in mind was the familiar rule that allows one party to comment on the failure of another party to introduce relevant evidence which is peculiarly under his control. Counsel may point out to the trier of fact that one who withholds evidence probably does so because the evidence is unfavorable to his case. ${ }^{45}$ This rule of evidence

$39 \mathrm{Id}$. at 154. This holding has been distinguished in other recent cases. Cooper v. United States, 337 F.2d 538, 540 (D.C. Cir. 1964); United States v. Parness, 331 F.2d 703, 704, 705 (3d Cir.), cert. denied, 377 U.S. 993 (1964); Peel v. United States, 316 F.2d 907, 912 (5th Cir. 1963); Coleman v. Denno, 223 F. Supp. 938, 945 (S.D.N.Y. 1963), affd, 330 F.2d 441 (2d Cir.), cert. denied, 377 U.S. 1003 (1964).

40308 F.2d at 143.

41 See the denial of the petition for a rehearing, 324 F.2d 375 (1963).

42308 F.2d at 144-54.

43 Id. at 143 .

44 "In all criminal prosecutions, the accused shall enjoy the right . . . to be confronted with the witnesses against him ...." U.S. Consr. amend. VI.

452 WigMORE, EvIDENCE $\S 285$ (3d ed. 1940). But see id. § 290, at 176: "So far as affects the prosecution, there is no rule requiring that all eye-witnesses shall be called; therefore it is commonly said in that connection that the prosecution's failure to call an eye-witness is not open to inference ...; but there can be no such general principle, for sometimes the inference would be well founded." 
has not usually been thought of as a constitutional right, but a defendant who has been denied the opportunity to point out to the jury inferences of conceded probative value may well have been denied a fair trial. ${ }^{46}$

The inference that the testifying defendant's counsel in De Luna sought to draw, however, was neither admissible nor probative. It was observed previously that inferences from the claim of privilege against self-incrimination by a witness are inadmissible against a defendant on the theory that generally they lack probative value. ${ }^{47}$ It was also observed that there are circumstances in which inferences from the claim of privilege might have some probative value, ${ }^{48}$ but the De Luna case presents no such circumstance. The prosecutor's evidence tended to show that the two defendants, Gomez and De Luna, were guilty of possession of narcotics. Gomez took the stand to testify that De Luna alone was guilty, and his counsel sought to buttress that testimony by contrasting Gomez' willingness to speak with the silence of De Luna. De Luna's silence may or may not have been indicative of his own guilt, but it certainly did not tend to prove the innocence of Gomez. Most likely De Luna declined to take the stand because he was advised that it would be better for his defense if he did not, and not because he was concealing the innocence of Gomez.

The court dealt only with the comments of Gomez' counsel on the failure of De Luna to testify against Gomez. The comments would also have lacked probative value if they had been comments on the failure of the prosecutor to introduce relevant evidence against Gomez, i.e., the testimony of De Luna. The reason the prosecutor failed to obtain that testimony is only too obvious; De Luna chose not to testify. ${ }^{49}$ Hence, there is no reason to believe that that testimony, if presented, would have been favorable to Gomez.

If due to the joint trial Gomez loses the right to comment on De Luna's silence, which has no probative value as evidence and merely tends to inflame the minds of the jury with prejudice, so much the better. ${ }^{50} \mathrm{His}$ case would stand on an entirely different footing, however,

40 However, the value of such inferences is not universally conceded. See Note, Evidence: Failure to Call Available Witnesses, 34 CoRNell L.Q. 637 (1949).

47 See text accompanying notes 5-6 supra. On this theory, the court in Billeci v. United States, 184 F.2d 394,398 (D.C. Cir. 1950), said in a dictum that inferences could not be drawn in favor of either party.

48 See text accompanying notes 7-8 supra.

49 Wigmore states that no inference should be drawn when the witness is unavailable. 2 Wigmore, EvDENCE $\$ 286$ (3d ed. 1940). If the witness does not claim his privilege he is equally available to both parties, and neither should be allowed to draw an inference. Id. at $\S 288$.

50 The case would be more difficult if Gomez' counsel had commented only on his own client's willingness to testify, with no reference to the silence of De Luna. A rather weak 
if his counsel had desired to call De Luna as a witness rather than to comment on his absence. If the joint trial makes it impossible for a defendant to call an important witness whom he could call in a separate trial, then certainly a severance ought to be granted. Constitutional sanction for a right to severance in such a case might be found in notions of due process or in the purpose of the sixth amendment's subpoena power. ${ }^{51}$ The right of an accused to have "compulsory process for obtaining Witnesses in his favor" is a nullity if procedural rules can make it impossible for competent witnesses to be called to the stand. ${ }^{52}$ However, a court which recently reversed a denial of severance did so on nonconstitutional grounds, holding that denial was an abuse of discretion in light of the prior open court statements of the codefendant exculpating the defendant.53

Nothing will be gained by granting a severance, however, if the codefendant continues to claim his privilege when called as a witness in the separate trial. For the same reason that Gomez' counsel should not have been granted a right to comment on the absence of De Luna from the stand at the joint trial, he should not be allowed to draw any inferences from the failure of De Luna to take the stand at the joint trial, and he should not be allowed to draw any inferences from the failure of De Luna to answer questions as a witness.

Hence a severance should be granted to allow one defendant to call the other as a witness only if the witness will give testimony having probative value. The problem is to decide when he will do so. Under recent Supreme Court decisions, the witness apparently cannot be ordered to testify even if he has already been tried and convicted and penalized for the crime about which the questions are asked, and even if the questions do not appear to call for incriminating answers. ${ }^{54} \mathrm{He}$ can be ordered to testify only if granted a sweeping immunity from state and federal prosecutions based on "the compelled testimony and

inference might be drawn that Gomez' willingness to testify is indicative of his innocence, and De Luna might complain that the comment indirectly called the attention of the jury to his own silence. An argument for granting a severance to allow this comment to be made without prejudice to the other defendant would be appealing if joint trials had not triumphed over far more serious claims of disadvantage. Hayes v. United States, 329 F.2d 209, 221-22 (8th Cir. 1964), distinguishes De Luna by holding a fair trial was not denied when one defendant was not allowed to comment on the failure of his codefendants to testify.

51 "In all criminal prosecutions, the accused shall . . have compulsory process for obtaining Witnesses in his favor. ..." U.S. ConsT. amend. VI.

52 Two decisions have refused to grant a severance to enable the codefendant to be called. United States v. Van Allen, 28 F.R.D. 329 (S.D.N.Y. 1961); United States v. Berman, 24 F.R.D. 26 (S.D.N.X. 1959).

53 United States v. Echeles, No. 14774, 7th Cir. Sept. 2, 1965.

54 Malloy v. Hogan, 378 U.S. 1 (1964). 
its fruits." 55 Some day a defendant may argue that he is denied a fair trial if such immunity is not granted to a vital defense witness to obtain his testimony. It may be absurd to suppose that courts would allow one accused accomplice to obtain the freedom of the other so easily. The argument would not be absurd at all, however, if the defendant who refused to testify were tried first. Granting immunity from subsequent related prosecutions $s^{56}$ to allow this defendant to testify on behalf of another might be a small price for the community to pay in the interests of a fair trial.

Even if sufficient immunity cannot be granted, and the witness may not be ordered to testify, he may choose to testify in a separate trial when his liberty is not so directly at stake. Whether he will do so will depend on imponderables that vary with every individual and every situation. When faced with a motion for severance, the trial court may be unable to decide whether the nontestifying defendant would be willing to testify in a separate trial of the other defendant, even if his own trial were held first. Because most judges consider joint trials to be vital to trial administration, they will be very reluctant to grant severances on the mere possibility of obtaining testimony. When the silent defendant agrees to testify at a separate trial, a severance should be granted. In all other cases it is necessary to balance the likelihood of obtaining testimony against the value of joint trials. If it seems objectionable to give administrative convenience precedence over the possibility that a defendant's case may be harmed, the only reply is that the institution of the joint trial has prevailed over far more persuasive claims of injury.

55 Murphy v. Waterfront Comm'n, 378 U.S. 52, 79 (1964).

56 The state of the law which allows the possibility of separate convictions under state and federal law for the same criminal actions, and the possibility of separate prosecutions under the law of a single jurisdiction for related offenses growing out of the same acts has been subjected to severe attack by judges as well as commentators. See, e.g., the opinions collected in Donnelly, Goldstein \& Schwartz, Criminal Law 395-401 (1962). 